Article

\title{
The Role of Access to Finance in Explaining Cross-National Variation in Entrepreneurial Activity: A Panel Data Approach
}

\author{
Sorin Gabriel Anton 1,* (1) and Ionel Bostan ${ }^{2}$ \\ 1 Faculty of Economics and Business Administration, Alexandru Ioan Cuza University of Iasi, Carol I Avenue, \\ No. 11, 700506 Iaşi, Romania \\ 2 Faculty of Law and Administrative Sciences, Stefan cel Mare University of Suceava, Str. Universitatii 13, \\ 720229 Suceava, Romania; ionel_bostan@yahoo.com \\ * Correspondence: sorin.anton@uaic.ro; Tel.: +40-232-201-450
}

Received: 31 July 2017; Accepted: 24 October 2017; Published: 29 October 2017

\begin{abstract}
The aim of the paper is to investigate to what extent access to finance explains differences in entrepreneurial activity across European Union (EU) member countries. We use a dataset containing information across countries and time to investigate the determinants of entrepreneurial activity in twenty-five EU members over the period between 2007 and 2013. Our sample comprises both periods of difficult access to finance and periods of excessive liquidities. Employing a panel data model with fixed effects, we found a positive relationship between access to finance and entrepreneurial activities. Furthermore, we showed that this positive relationship is more important for the individuals who believe they have the required skills and knowledge to start a business. The results proved to be robust when we employed different measures of entrepreneurial activity and several proxies for access to finance. Our findings provide empirical evidence for the need of policy initiatives at national and EU level to facilitate the creation of sustainable new ventures.
\end{abstract}

Keywords: new business sustainability; entrepreneurial activity; access to finance; competitiveness; European Union; financial crisis

\section{Introduction}

In the extant literature, there is a broad consensus on the positive relationship between entrepreneurial activity, on the one hand, and innovation, job creation, and economic development, on the other hand. Several papers have shown that entrepreneurial firms are the backbone of local, regional, and national economies, traditionally providing the majority of employment and innovation [1,2]. As highlighted by Niţu-Antonie et al. [3], a higher level of entrepreneurial activity may generate "economic and non-economic value for the environmental, economic and social dimension of sustainability". In the light of the latest global financial crisis, entrepreneurship is increasingly seen as a way to support (youth) employment and competitiveness of the European economy. A recent paper highlighted that entrepreneurship and entrepreneurial activity can play a significant role in supporting recovery from the recession and sustainable economic growth [4].

Given the important role of entrepreneurial activity for sustainable economic growth, policy makers across the world have initiated several public policies for creating new ventures. However, supporting entrepreneurship through public policies requires a thorough understanding of its determinants and, subsequently, the adoption of appropriate measures [5-7]. Starting with 2006, OECD within the Entrepreneurship Indicators Programme (EIP) identified six main thematic determinants of entrepreneurship, namely: (1) regulatory framework; (2) market conditions; (3) access to finance; (4) creation and diffusion of knowledge; (5) entrepreneurial capabilities; and (6) entrepreneurial culture. 
Several papers highlighted the key role played by access to finance in supporting entrepreneurship and small and medium-sized enterprises (SMEs). The lack of financial resources is often considered as one of the main causes for not starting a new venture. Some studies showed that access to finance varies greatly from one country to another and might represent a key factor for entrepreneurial activity [8-11]. Previous papers measured access to finance in terms of access to credit (debt) or access to equity. We consider that these proxies are insufficient as, in the first stages of their evolution, ventures are financing their activity and growth using equity and debt.

The aim of the paper is to provide new evidence on the determinants of differences in entrepreneurial activity across EU countries over the period between 2007 and 2013. Employing a panel data model with fixed effects, we found a positive relationship between access to finance and entrepreneurial activities. Our findings proved to be robust when we employed different measures of entrepreneurial activity and several proxies for access to finance.

The paper contributes to the literature on the country-level determinants of entrepreneurship in three major ways. To the best of our knowledge, this is the first study to examine the effects of financial constraints on entrepreneurial activity in EU countries in the light of the latest global financial crisis. Secondly, we contribute to the extant literature through the expanding of knowledge on the determinants of cross-national variations in entrepreneurial activity across countries using new proxies for access to finance. Contrary to previous studies, we employ one proxy that accounts for at the same time for access to equity and to debt. Thirdly, we contribute to the extant literature by testing the existence of an additional impact of financial and human capital on entrepreneurial activity.

The rest of this paper is structured as follows. Section 2 reviews chronologically some of the key literature on the main determinants of differences in entrepreneurial activities across countries. In Section 3, an explanation of data and the methodology employed in our paper is provided. We further present and discuss the key results of the study in Section 4 . Section 5 concludes the paper and highlights the limits of our research.

\section{Literature Review}

In explaining differences in entrepreneurial activities across countries, one has to take into account numerous factors, including individual characteristics, social values, and the entrepreneurship ecosystem (for instance, access to finance, education and R\&D transfer, physical and professional infrastructure). Numerous papers have explored the determinants of entrepreneurship, but only several have tried to explain the differences in entrepreneurial activity across countries.

Most of the previous studies focused on the role played by cultural and institutional factors in explaining differences in entrepreneurial activities across countries. Wennekers et al. [12] showed that cross-country variations in entrepreneurial activity are explained by cultural and institutional components. Robson [13] found that political structure has a significant effect on entrepreneurial activities, the rate of entrepreneurial activity being lower in countries which experienced a period of communist rule. Using data of the 25 member states of the EU as well as the U.S., Freytag and Thurik [14] found that country specific (cultural) factors explain the preference for entrepreneurship. Estrin and Mickiewicz [15] highlighted the role of institutions and generational change on entrepreneurial activity in transition economies from Central and Eastern Europe. Ardagna and Lusardi [16] found that high level of entry regulation has negative effects on entrepreneurial activity and these effects are stronger on certain types of people (individuals with business skills and women). Klapper and Love [17] showed that the latest global financial crisis had negative effects on entrepreneurial activities. Studying the entrepreneurial intention across China, US, and Belgium, Shinnar et al. [18] showed that fear of failure decreases the intention to undertake an entrepreneurial activity. Employing a cross-section of 72 countries, Goel et al. [19] found that the overall level of economic freedom has a positive and statistically significant influence on entrepreneurship.

Several papers $[10,11,20-22]$ include the access to finance in the determinants of entrepreneurial activities across countries and the results are mixed. According to Kerr and Nanda [20], there are two 
main streams of research on the relevance of financing constraints for entrepreneurship. The first stream of research focuses on the impact of financial market development (e.g., the depth of credit markets) on entrepreneurs' access to finance and rate of firm formation. The second strand of literature uses individual level data to assess how propensities to start new ventures relate to personal wealth/capital.

Regarding the first line of research, Klapper et al. [21] analyzed the determinants of firm formation in 101 countries for the maximum time period from 2000 to 2008 . Their results show that access to finance (measured as domestic credit divided by GDP) is positively associated with only for one measure of new firm formation (entry per capita). However, for other two measures of new firm formation (total business density and entry rates), the results are not statistically significant. Nielsen [22] found that one percentage-point increase in the percentage of the population engaged in venture capital (a proxy for the size of the venture capital industry) is associated with a 0.753 percentage-point increase in entrepreneurial activity. Employing a sample of 10 EU countries, Morales Urrutia and Rodil Marzábal [11] found a positive relationship between access to finance (measured as private credit to GDP) and entrepreneurship. In the extant literature, access to finance refers mainly to access to credit or to venture capital. As highlighted by Fraser et al. [23], alternative financial sources for starting a business such as bootstrap finance, crowdfunding, and supply chain finance are not included in the existing proxies for access to finance and thus insufficiently researched.

In the context of the second line of research, Blanchflower and Oswald [24] found that the probability of being self-employed depends on having an entrepreneurial vision and having access to the necessary financial resources to implement it. Grilo and Irigoyen [25] analyzed the determinants of latent and actual entrepreneurship using data from the Flash Eurobarometer Survey on Entrepreneurship conducted during September/October 2000 on a random sample from the 15 EU Member States and the US. Contrary to their expectations, the results show the perceived lack of financial support does not seem to have a significant impact on the revealed preference towards self-employment (latent entrepreneurship). However, the lack of financial support has a significant negative impact on actual entrepreneurship. Using individual- and country-level data, De Clercq et al. [26] found that people's access to financial capital (household income), human capital (entrepreneurship-specific knowledge) and social capital (exposure to other entrepreneurs) enhances the likelihood to start a new business.

There is much consensus that access to financial resources is an important determinant of entrepreneurship. Banks usually are reluctant to lend money to early-stage and seed businesses given their lack of sufficient collateral and/or track record, high risks involved and poor business performance. For EU countries, the European Central Bank (ECB) and the European Commission (EC) are conducting every two years surveys on the SMEs' access to finance (Survey on the Access to Finance of Small- and Medium-sized Enterprises (SAFE) [27]. As presented in Table 1, access to finance was the second most pressing problem for SMEs in the EU, after the "finding customers" concern over the period between 2009 and 2013.

Table 1. SMEs' most pressing problem in the EU over the period 2009-2013.

\begin{tabular}{ccccc}
\hline & $\mathbf{2 0 0 9}$ & $\mathbf{2 0 1 1}$ & \multicolumn{2}{c}{$\mathbf{2 0 1 3}$} \\
\cline { 2 - 5 } & $\mathbf{E U 2 7}$ & $\mathbf{E U 2 7}$ & EU28 & EURO AREA \\
\hline Finding customers & 29.10 & 24.10 & 22.4 & 24.1 \\
Competition & 12.80 & 14.60 & 13.8 & 11.7 \\
Access to finance & 16.10 & 15.10 & 15.4 & 16.3 \\
Costs of production or labor & 7.70 & 12.20 & 12.9 & 13.9 \\
Availability of skilled staff or experienced managers & 7.80 & 13.60 & 14.2 & 14.2 \\
Regulation & 7.20 & 7.70 & 14.2 & 12.6 \\
Other & 15.00 & 9.70 & 7.1 & 7.1 \\
DK/NA & 4.40 & 2.90 & - & - \\
\hline
\end{tabular}

Source: European Central Bank [27]. 
Our aim is to examine to which extent these concerns expressed in the surveys are really affecting the entrepreneurial activity. This paper fills the gap in the literature by examining the effects of access to finance on entrepreneurial activity across EU countries over the period between 2007 and 2013. The EU member states represent an interesting sample to study the effect of financing gap on entrepreneurial activity since access to finance was severely restricted during the latest global financial crisis and also during the sovereign debt crisis. Furthermore, at the EU level, supporting entrepreneurship and SMEs development represents a top priority, given their potential to foster economic growth, job creation, and innovation. Thus, various initiatives (e.g., Small Business Act) and public policies at national and EU level aim to support entrepreneurial activity. However, there are major differences between EU member states in terms of access to appropriate financing and entrepreneurial activity.

\section{Materials and Methods}

Our analysis combines individual-level entrepreneurship with macroeconomic data for $25 \mathrm{EU}$ member states, both upper-middle-income and high-income economies (according to World Bank's classification). We excluded from our sample three members (Bulgaria, Cyprus, and Malta) of the EU due to an absence of values on Global Entrepreneurship Monitor (GEM).

Firstly, we exploit the GEM database (Adult Population Survey), the world's largest survey-based study of entrepreneurial activity, which covers more than 60 developed and developing economies since it was established in 1999 and which includes all startups, regardless of their legal status. For each country, GEM covers a representative sample of at least 2000 individuals, drawn from the adult population (18-64 years). Macroeconomic data come from different international sources: The European Commission (EC) and World Bank (Doing Business and World Development Indicators). Data on Global Competitiveness Index (GCI) has been retrieved from World Economic Forum. Data on corruption and political stability are obtained from World Bank's Worldwide Governance Indicator Project, while data for Index of Economic Freedom were provided by Heritage Foundation.

We employ total entrepreneurial activity (TEA) as a proxy for entrepreneurial activity in EU member countries over the period between 2007 and 2013. The total early-stage entrepreneurial activity rate, the most important measure of GEM, reflects the share of adults in the population of 18 to 64 years old who is a nascent entrepreneur or owner-manager of a new business. It includes individuals who are actively involved in setting up a business they will own or co-own (Nascent Entrepreneurship Rate (NER)), respectively, individuals who are owning and managing "a running business that has paid salaries, wages, or any other payments to the owners for more than three months, but not more than 42 months" (New Business Ownership Rate (NBOR)) [28]. To test the robustness of our findings, we will run the models using as dependent variables NER and NBOR.

To explain the influence of access to finance on the entrepreneurial activity, we employed two alternative variables for access to finance, namely: the SME access to finance index (SMAF) and informal investors rate (IIR). These variables provide different insights on access to finance.

The SMAF index provides an indication of the change in the conditions of SMEs' access to finance (debt and equity) over time for the EU and its Member States. The index is computed as a weighted mean of two sub-indices: the access to debt finance index $(85 \%)$ and the access to equity finance index $(15 \%)$. The first sub-index, commonly associated with more mature firms, is computed based on nine indicators: percent of firms using bank loans; interest rates on loans up to 250 thousand $€$; interest rates for overdrafts; percent of firms using bank overdraft, credit line or credit cards overdraft; percent of firms using leasing or hire purchase or factoring; percent of companies not applying for bank loan because of possible rejection; percent of firms "applied but did not get everything requested"; rejected loan applications and unacceptable loan offers; and willingness of banks to provide a loan. The second sub-index is constructed based on the following 5 indicators: total venture capital investment in thousands of $€$ (percent of GDP); number of venture capital beneficiary SMEs (scaled by GDP); total volumes invested by business angels in thousands of $€$ (percent of GDP); number of deals where business angels invested (percent of GDP); percent of firms feeling confident to talk about financing 
with equity investors/venture capital firms. Given his composition, the access to equity finance index is commonly associated with early stage ventures. Higher values of the SMAF index and its sub-indices show better performance of the access to finance indicators relative to the EU level in 2007 $(100=$ EU 2007). Year-on-year increases indicate that the country's SMEs are relatively improving their access to finance. Higher availability of external financial resources for existing and potential entrepreneurs supports new ventures creation and development of existing one [11,29-31]. The main advantages of this proxy for access to finance are: (1) it allows comparison across countries using the same benchmark-access to finance at EU level in 2007 (before the onset of global financial crisis); and (2) contrary to previous proxies, our variable includes not only access to debt but also access to equity. This fact is important, as, in the first stages of their evolution, SMEs are financing their activity and growth from both sources. However, this proxy has an important drawback: some of the indicators used in his computation are also determinants of entrepreneurial activity.

IIR captures the informal investments made by friends, family members, and colleagues in a new venture, started by someone else, in the last three years [28]. The impact of informal investment on entrepreneurial activity is significant. In the early stages of a venture's life cycle, entrepreneurs rely mainly on personal funding. As the level of personal resources is limited and because entrepreneurs cannot secure outside funding (through venture capital or banks), they seek financing from friends, family members, and colleagues for their start-up capital needs. These sources of financing are particularly important in the new member states where the level of funds provided by venture capital firms and business angels is very low. A higher value of these variables indicates more financial resources available to launch and sustain new ventures. In contrast to the previous variable, IIR measures the access to informal funding for start-ups and growing firms. We posit the following research hypothesis:

Hypothesis 1 (H1). Countries with greater access to financial resources have more entrepreneurial activity.

Following the list of indicators of entrepreneurial determinants set by OECD—Eurostat Entrepreneurship Indicators Programme (EIP) [32] and the extant literature, we include the following control variables in our models: enforcing contracts (cost in percent of claim) as proxy for regulatory framework; export burdens as proxy for market conditions; perceived capabilities as variable explaining entrepreneurial capabilities; and fear of failure rate for entrepreneurship culture. Additionally, following the extant literature, we employed GDP per capita growth rate (GDPCG) as a proxy for economic growth, GCI as a measure of national competitiveness, the level of corruption, political stability, and index of economic freedom (see Table 2 for a detailed description of each variable according to the original source).

As already explained in the extant literature [16,33], regulatory constraints (e.g., enforcing contracts) could have a negative impact on TEA. Using a sample of twenty-seven Organization for Economic Cooperation and Development (OECD) member countries, Sobel et al. [33] showed that barriers to entry and government regulation discourage people from starting a business. According to their results, $1 \%$ increase in the average tariff rate is associated with an $8 \%$ decrease in total entrepreneurial activity (TEA).

Export burdens (measured as the number of documents and signatures and time necessary to comply with all procedures required to export goods and services) is another determinant that was used in the previous studies. We expected a negative relationship between fear of failure and entrepreneurial activity.

Following Costa and Mainardes [34], we include in our estimations individual's risk perception measured by fear of failure. According to the extant literature [18], the relationship between fear of failure and TEA is negative: a higher value for fear of failing prohibits him/her from starting a venture. We expected a negative relationship between fear of failure and entrepreneurial activity. 
Individual characteristics are also important determinants of entrepreneurial activity. Individual who believe they have the required skills and knowledge are more likely to start a business. We expected a positive relationship between perceived capabilities (or self-efficacy) and TEA.

Table 2. Variables employed in the panel data analysis.

\begin{tabular}{|c|c|c|}
\hline Name & Definition & Source \\
\hline $\begin{array}{l}\text { The total early-stage } \\
\text { entrepreneurial activity } \\
\text { rate (TEA) }\end{array}$ & $\begin{array}{l}\text { The percentage of individuals aged 18-64 in an economy who are a } \\
\text { nascent entrepreneur or owner-manager of a new business. }\end{array}$ & $\begin{array}{l}\text { Global Entrepreneurship } \\
\text { Monitor }\end{array}$ \\
\hline $\begin{array}{l}\text { Nascent } \\
\text { Entrepreneurship Rate } \\
\text { (NER) }\end{array}$ & $\begin{array}{l}\text { The percentage of individuals aged } 18-64 \text { in an economy who are } \\
\text { currently a nascent entrepreneur (i.e., actively involved in setting up a } \\
\text { business they will own or co-own; this business has not paid salaries, } \\
\text { wages, or any other payments to the owners for more than } \\
\text { three months). }\end{array}$ & $\begin{array}{l}\text { Global Entrepreneurship } \\
\text { Monitor }\end{array}$ \\
\hline $\begin{array}{l}\text { New Business } \\
\text { Ownership Rate (NBOR) }\end{array}$ & $\begin{array}{l}\text { The percentage of individuals aged } 18-64 \text { in an economy who are } \\
\text { currently an owner-manager of a new business (i.e., owning and } \\
\text { managing a running business that has paid salaries, wages, or any other } \\
\text { payments to the owners for more than three months, but not more than } \\
42 \text { months). }\end{array}$ & $\begin{array}{l}\text { Global Entrepreneurship } \\
\text { Monitor }\end{array}$ \\
\hline SMAF index (SMAF) & $\begin{array}{l}\text { The SMAF index provides an indication of the changing conditions of } \\
\text { SMEs' access to finance (debt and equity) over time for the EU and its } \\
\text { Member States. It is computed as a weighted mean of two sub-indices: } \\
\text { the access to debt finance index ( } 85 \% \text { ) and the access to equity finance } \\
\text { index }(15 \%) \text {. High values in the SMAF index and its sub-indices } \\
\text { indicate better performance of the access to finance indicators relative to } \\
\text { the EU level. }\end{array}$ & European Commission \\
\hline $\begin{array}{l}\text { Informal Investors Rate } \\
\text { (IIR) }\end{array}$ & $\begin{array}{l}\text { Percentage of 18-64 population who have personally provided funds } \\
\text { for a new business, started by someone else, in the past three years. }\end{array}$ & $\begin{array}{l}\text { Global Entrepreneurship } \\
\text { Monitor }\end{array}$ \\
\hline $\begin{array}{c}\text { Enforcing } \\
\text { contracts-Cost in } \\
\text { percent of claim (ENCO) }\end{array}$ & $\begin{array}{l}\text { Cost is recorded as a percentage of the claim, assumed to be equivalent } \\
\text { to } 200 \% \text { of income per capita. }\end{array}$ & $\begin{array}{l}\text { World Bank, Doing } \\
\text { Business }\end{array}$ \\
\hline Export burdens (EXBU) & $\begin{array}{l}\text { An average of three measurements: (1) number of all documents } \\
\text { required to export goods; (2) number of signatures required to export } \\
\text { goods; and (3) time necessary to comply with all procedures required to } \\
\text { export goods. }\end{array}$ & $\begin{array}{l}\text { World Bank, Doing } \\
\text { Business }\end{array}$ \\
\hline Fear of Failure Rate (FFR) & $\begin{array}{l}\text { Percentage of 18-64 population with positive perceived opportunities } \\
\text { who indicate that fear of failure would prevent them from setting up } \\
\text { a business. }\end{array}$ & $\begin{array}{l}\text { Global Entrepreneurship } \\
\text { Monitor }\end{array}$ \\
\hline $\begin{array}{l}\text { Perceived Capabilities } \\
\text { (PECA) }\end{array}$ & $\begin{array}{l}\text { Percentage of } 18-64 \text { population who believe to have the required skills } \\
\text { and knowledge to start a business. }\end{array}$ & $\begin{array}{l}\text { Global Entrepreneurship } \\
\text { Monitor }\end{array}$ \\
\hline $\begin{array}{l}\text { GDP per capita growth } \\
\text { (GDPCG) }\end{array}$ & $\begin{array}{l}\text { Annual percentage growth rate of GDP per capita based on constant } \\
\text { local currency. }\end{array}$ & $\begin{array}{c}\text { World Bank, World } \\
\text { Development Indicators }\end{array}$ \\
\hline $\begin{array}{l}\text { Global Competitiveness } \\
\text { Index (GCI) }\end{array}$ & $\begin{array}{l}\text { GCI measures different aspects of competitiveness in } 12 \text { pillars, which } \\
\text { are scored on a scale of } 1 \text { to } 7,7 \text { being the most competitive. } \\
\text { Competitiveness is defined as "the set of institutions, policies, and } \\
\text { factors that determine the level of productivity of a country". }\end{array}$ & World Economic Forum \\
\hline Corruption (CORRUP) & $\begin{array}{l}\text { CORRUP measures a wide range of issues associated with corruption } \\
\text { (e.g., frequency and size of additional payments needed to get things } \\
\text { done). The value of this index ranged from approximately }-2.5 \\
\text { (low control of corruption) to } 2.5 \text { (low control of corruption). We have } \\
\text { rescaled this index by multiplying it with }-1 \text {, so that higher values } \\
\text { represent more corrupt societies. }\end{array}$ & $\begin{array}{l}\text { World Bank, Worldwide } \\
\text { Governance Indicator } \\
\text { Project }\end{array}$ \\
\hline Political stability (POL) & $\begin{array}{l}\text { Pol measures perceptions of the likelihood of political instability } \\
\text { and/or politically-motivated violence, including terrorism. The value } \\
\text { of this index ranged from approximately }-2.5 \text { (political instability) to } \\
2.5 \text { (political stability). }\end{array}$ & $\begin{array}{l}\text { World Bank, Worldwide } \\
\text { Governance Indicator } \\
\text { Project }\end{array}$ \\
\hline Economic freedom (IEF) & $\begin{array}{l}\text { The index of economic freedom comprises } 12 \text { quantitative and } \\
\text { qualitative factors, grouped into four pillars of economic freedom: } \\
\text { rule of law, government size, regulatory efficiency and open markets. } \\
\text { The value of the index ranged from } 0 \text { to } 100 \text { (the highest level of } \\
\text { economic freedom). }\end{array}$ & Heritage Foundation \\
\hline
\end{tabular}


The relationship between economic growth and entrepreneurial activity is complex. On the one hand, a high level of economic growth (measured as GDP per capita growth) can provide significant environmental opportunities and thus facilitate new-firm formation. On the other hand, economic development induces higher real wages and consequently lowers motivation for entrepreneurial activities. Several papers have found a U-shaped impact of economic growth on entrepreneurial activity [35-37]. Therefore, we expect a U-shaped relationship between GDP per capita growth and entrepreneurial activity.

National competitiveness is expected to have a negative impact on TEA, because more competitive economies can offer better jobs and thus decrease entrepreneurial activity. World Economic Forum [38] highlighted that more competitive economies register lower early-stage entrepreneurial activity, while less competitive economies have higher rates of entrepreneurial activity.

The relation between corruption and entrepreneurial activity is controversial in the extant literature. On the one hand, corruption practices (e.g., bribery) may increase the transaction costs of starting new ventures. On the other hand, some studies argued that corruption might grease the wheels' of entrepreneurship. For example, Dreher and Gassebner [39] studied 43 countries over the period 2003-2005 and found that corruption facilities new firm entry in highly regulated economies. Therefore, we have no expectations regarding the relationship between corruption and entrepreneurial activity.

Political instability can discourage people from becoming entrepreneurs by providing uncertainty on the short and medium term. We employ the index of political stability and absence of violence/terrorism developed by World Bank. We expect a positive relationship between political stability and entrepreneurial activity.

According to Goel et al. [19], economic freedom represents a major determinant of the level of entrepreneurial activity across countries. A higher level of economic freedom has a positive effect on entrepreneurial activity as individuals feel free to set up new ventures and also to experiment (entrepreneurial trial and error). We employ the Index of economic freedom provided by Heritage Foundation as it covers multiple aspects of economic freedom (rule of law, government size, regulatory efficiency and open markets). We expect a positive relationship between economic freedom and entrepreneurial activity.

To test the theoretical determinants of entrepreneurship, the following models include relevant explanatory variables that influence the national level of entrepreneurial activity:

$$
\begin{aligned}
\text {TEA }_{i t}=c_{0} & +c_{1} \times \text { Access to finance variable } e_{i, t}+c_{2} \times E N C O_{i, t}+c_{3} \times E X B U_{i, t}+ \\
c_{4} & \times F F R_{i, t}+c_{5} \times P E C A_{i, t}+c_{6} \times G D P C G_{i, t-1}+c_{7} \times G C I_{i, t} \\
& +c_{8} \times \operatorname{CORRUP}_{i, t}+c_{9} \times P O L_{i, t}+c_{10} \times I E F_{i, t}+u_{i, t}
\end{aligned}
$$

where $i$ and $t$ denote the country and year for each variable. Following relevant studies on the determinants of entrepreneurial activity, GDP growth is lagged one year to clarify the causality relationship.

We estimated our model specification (Equation (1)) using two different methods. Firstly, this study used a pooled ordinary least-squares regression model (OLS) as a benchmark. Secondly, we draw on a panel fixed effects (FE) model. The panel data methodology seems to be the most appropriate for at least two reasons. Firstly, this method controls the so-called unobservable constant heterogeneity. Each country in the sample has its own specificity that will be kept throughout the study period (e.g., culture). A pooling analysis of all these countries without noticing these peculiar characteristics could cause an omission bias and distort the results. Secondly, it controls for potential endogeneity generated by omitted variables. The fixed-effects general specification can be described by the following equation:

$$
Y_{i, t}=\alpha_{i}+X_{i, t} \times \beta+\epsilon_{i, t}
$$


in which $Y_{i, t}$ is the dependent variable observed for country $i$ at time $t, X_{i, t}$ is the time-variant regressor matrix, $\alpha_{i}$ represents an unknown country-specific constant (the "fixed effect") and $\epsilon_{i, t}$ is the error term. To check the appropriateness of fixed-effects panel data estimation, we ran a Hausman test. The results of the Hausman test (not reported here, but available upon request) reveal that the fixed-effect model was to be used.

\section{Results and Discussion}

\subsection{Descriptive Statistics and Correlation}

Table 3 shows descriptive statistics for the full unbalanced panel dataset with 25 countries and 175 country-time observations. Similar to Bosma and Schutjens [40] we found that cross-country variation in early-stage entrepreneurial activity is very persistent over the period between 2007 and 2013. The standard deviation of TEA is 2.40, indicating how diverse our sample is with respect to the entrepreneurial activity. The highest levels of entrepreneurial activity are found in new member states of European Union, Estonia registering the highest value in 2012 (14.30\%). In the panel data, the minimum level of entrepreneurial activity is registered in Hungary in $2005(1.9 \%)$. The higher levels of entrepreneurial activity in the new EU member countries from CEE are most likely due to the poor labor market and lack of alternative economic opportunities.

Table 3. Descriptive Statistics.

\begin{tabular}{ccccccc}
\hline Variable & Mean & Median & Maximum & Minimum & Std. Dev. & Observations \\
\hline TEA & 6.48 & 5.81 & 14.30 & 1.90 & 2.40 & 208 \\
NER & 3.87 & 3.50 & 9.50 & 1.10 & 1.56 & 208 \\
NBOR & 2.74 & 2.50 & 6.40 & 0.40 & 1.17 & 208 \\
SMAF & 104.24 & 105.93 & 126.45 & 74.57 & 10.98 & 175 \\
IIR & 3.48 & 3.10 & 10.60 & 0.60 & 1.79 & 203 \\
ENCO & 20.89 & 18.60 & 40.50 & 8.80 & 7.35 & 273 \\
EXBU & 4.12 & 4.00 & 7.00 & 2.00 & 1.02 & 249 \\
FFR & 36.99 & 36.44 & 61.58 & 15.00 & 7.19 & 208 \\
PECA & 42.66 & 42.53 & 61.00 & 15.00 & 7.80 & 208 \\
GDPCG & 1.47 & 1.69 & 13.27 & -16.59 & 4.31 & 250 \\
GCI & 4.76 & 4.61 & 5.61 & 3.86 & 0.50 & 200 \\
CORRUP & -1.06 & -1.01 & 0.27 & -2.56 & 0.83 & 275 \\
POL & 0.76 & 0.78 & 1.59 & -0.47 & 0.40 & 275 \\
IEF & 69.02 & 69.80 & 82.60 & 53.40 & 6.19 & 175 \\
\hline
\end{tabular}

Source: Research results.

Regarding the access to finance, we notice significant inter-country and over time differences. SMAF index recorded the highest values in western countries (France, Austria, and Finland), whereas Central and Eastern European countries scored the lowest values (below 100). Additionally, between 2008 and 2009, SMAF index recorded the lowest values for almost all countries in the sample, revealing the financial constraints the SMEs faced as a consequence of the global financial crisis (see Appendix A, Table A1). The second variable capturing access to finance (IIR) presents also significant differences from one country to another in the sample, the highest values being recorded in the Baltic countries over the post-crisis period.

Appendix A (Table A2) presents the correlation matrix of dependent and independent variables. We notice a high level of correlation among the dependent variables-TEA and its subgroups (NER and NBOR) - that will be used later on alternatively in the models. Given that the correlation between CGI and CORRUP is very high, we will use alternatively these two variables in our estimations. As the correlation among the rest of independent variables is moderate, we consider that multicollinearity is unlikely to be a problem in our models. We notice a weak linear relationship between SMAF and 
the index of economic freedom, respectively no linear relationship between risk capital (IIR) and economic freedom.

\subsection{Empirical Results}

Table 4 reports the results of the estimations for SMAF index as a proxy for access to finance using pooled OLS (Column 2) and fixed effects panel model (Column 3). Our results show a positive relationship between access to finance and TEA. According to the fixed effects panel model, a one point increase in the SMAF index is associated with a $0.073 \%$ increase in TEA, and this effect is statistically significant at the $1 \%$ level. Regarding the personal characteristics, we find that a one percent increase in the population that believes they have the required skills and knowledge to start a business is associated with a $0.10 \%$ increase in TEA. The results of the fixed effects panel model suggest a strong positive relationship between the economic growth and the level of entrepreneurial activity.

Table 4. Empirical results: TEA models.

\begin{tabular}{|c|c|c|c|c|c|c|}
\hline \multirow{2}{*}{$\begin{array}{l}\text { Variables } \\
\text { (1) }\end{array}$} & \multicolumn{3}{|c|}{ Model 1} & \multicolumn{3}{|c|}{ Model 2} \\
\hline & $\begin{array}{l}\text { Pooled OLS } \\
\text { (2) }\end{array}$ & $\begin{array}{l}\text { FE } \\
(3)\end{array}$ & $\begin{array}{l}\text { FE } \\
(4)\end{array}$ & $\begin{array}{l}\text { Pooled OLS } \\
\text { (5) }\end{array}$ & $\begin{array}{l}\text { FE } \\
\text { (6) }\end{array}$ & $\begin{array}{l}\text { FE } \\
\text { (7) }\end{array}$ \\
\hline $\mathrm{C}$ & $\begin{array}{l}-21.93061 \\
(5.027516)\end{array}$ & $\begin{array}{c}-10.04788 \\
(7.754456)\end{array}$ & $\begin{array}{l}-34.27256 \\
(14.21133)\end{array}$ & $\begin{array}{l}-14.86944 \\
(3.436482)\end{array}$ & $\begin{array}{c}0.445007 \\
(7.704941)\end{array}$ & $\begin{array}{l}-0.870461 \\
(7.894868)\end{array}$ \\
\hline SMAF & $\begin{array}{l}0.041568 * \\
(0.021336)\end{array}$ & $\begin{array}{c}0.073161 \text { *** } \\
(0.022794)\end{array}$ & $\begin{array}{c}0.305305^{* *} \\
(0.117022)\end{array}$ & - & - & - \\
\hline IIR & - & - & - & $\begin{array}{c}0.661980 * * * \\
(0.092673)\end{array}$ & $\begin{array}{c}0.540958 * * * \\
(0.140804)\end{array}$ & $\begin{array}{l}1.110269 * \\
(0.729210)\end{array}$ \\
\hline ENCO & $\begin{array}{c}0.000476 \\
(0.029718)\end{array}$ & $\begin{array}{c}0.349322 \text { *** } \\
(0.098547)\end{array}$ & $\begin{array}{c}0.284711^{* * *} \\
(0.102188)\end{array}$ & $\begin{array}{l}-0.007071 \\
(0.025567)\end{array}$ & $\begin{array}{c}0.291547^{* * *} \\
(0.098525)\end{array}$ & $\begin{array}{c}0.295637^{* * *} \\
(0.098849)\end{array}$ \\
\hline EXBU & $\begin{array}{c}0.282568 \\
(0.229182)\end{array}$ & $\begin{array}{l}-0.683835 \\
(0.789425)\end{array}$ & $\begin{array}{c}-0.427290 \\
(0.787811)\end{array}$ & $\begin{array}{c}0.325443 \\
(0.200061)\end{array}$ & $\begin{array}{c}-1.583813^{* *} \\
(0.789387)\end{array}$ & $\begin{array}{c}-1.697131^{* *} \\
(0.803633)\end{array}$ \\
\hline FFR & $\begin{array}{c}0.074671 * * \\
(0.032688)\end{array}$ & $\begin{array}{c}0.084368^{* * *} \\
(0.031292)\end{array}$ & $\begin{array}{c}0.077339 * * \\
(0.031016)\end{array}$ & $\begin{array}{c}0.073598 * * \\
(0.028290)\end{array}$ & $\begin{array}{c}0.064761 \text { ** } \\
(0.031321)\end{array}$ & $\begin{array}{l}0.067882 * * \\
(0.031626)\end{array}$ \\
\hline PECA & $\begin{array}{c}0.128251 \text { *** } \\
(0.026899)\end{array}$ & $\begin{array}{l}0.105705^{* *} \\
(0.040401)\end{array}$ & $\begin{array}{c}0.626784^{* *} \\
(0.260845)\end{array}$ & $\begin{array}{c}0.121266^{* * *} \\
(0.023146)\end{array}$ & $\begin{array}{l}0.068110 * \\
(0.041666)\end{array}$ & $\begin{array}{l}0.108752 * \\
(0.065964)\end{array}$ \\
\hline GDPCG & $\begin{array}{c}0.128297^{* * *} \\
(0.044960)\end{array}$ & $\begin{array}{c}0.090023 * * \\
(0.039416)\end{array}$ & $\begin{array}{c}0.100638^{* *} \\
(0.039175)\end{array}$ & $\begin{array}{c}0.135372 * * * \\
(0.038655)\end{array}$ & $\begin{array}{l}0.097160 * * \\
(0.039586)\end{array}$ & $\begin{array}{l}0.089182 * * \\
(0.040910)\end{array}$ \\
\hline CORRUP & $\begin{array}{c}1.990596 \text { *** } \\
(0.421651)\end{array}$ & $\begin{array}{c}0.247336 \\
(1.576304)\end{array}$ & $\begin{array}{c}0.464625 \\
(1.556249)\end{array}$ & $\begin{array}{l}0.714302 * * \\
(0.389749)\end{array}$ & $\begin{array}{c}-0.245538 \\
(1.617843)\end{array}$ & $\begin{array}{l}-0.059192 \\
(1.637803)\end{array}$ \\
\hline POL & $\begin{array}{l}1.046421 * \\
(0.625432)\end{array}$ & $\begin{array}{c}-1.127888 \\
(1.280917)\end{array}$ & $\begin{array}{l}-0.817445 \\
(1.270914)\end{array}$ & $\begin{array}{c}0.534784 \\
(0.505573)\end{array}$ & $\begin{array}{r}-0.045479 \\
(1.231731)\end{array}$ & $\begin{array}{c}0.129936 \\
(1.253648)\end{array}$ \\
\hline IEF & $\begin{array}{l}0.234971 * * * \\
(0.051138)\end{array}$ & $\begin{array}{l}-0.030016 \\
(0.083755)\end{array}$ & $\begin{array}{l}-0.001247 \\
(0.083711)\end{array}$ & $\begin{array}{c}0.149215^{* * *} \\
(0.044254)\end{array}$ & $\begin{array}{l}-0.013241 \\
(0.086721)\end{array}$ & $\begin{array}{l}-0.014495 \\
(0.086904)\end{array}$ \\
\hline $\mathrm{SMAF} \times \mathrm{PECA}$ & & & $\begin{array}{l}0.05325 * * \\
(0.002635)\end{array}$ & & & \\
\hline $\mathrm{IIR} \times \mathrm{PECA}$ & & & & & & $\begin{array}{l}0.013159 * \\
(0.016536)\end{array}$ \\
\hline R-squared & 0.375563 & 0.750167 & 0.760069 & 0.550874 & 0.764906 & 0.766479 \\
\hline Adjusted R-squared & 0.330241 & 0.667723 & 0.677669 & 0.516906 & 0.683241 & 0.682014 \\
\hline $\begin{array}{l}\text { Total panel (unbalanced) } \\
\text { observations }\end{array}$ & 134 & 134 & 134 & 129 & 129 & 129 \\
\hline
\end{tabular}

Source: Research results. Notes: Standard error in parentheses; ${ }^{* *} p<0.01,{ }^{* *} p<0.05,{ }^{*} p<0.1$.

On the other hand, the results obtained for the two other variables presented in Column 3-enforcing contracts (ENCO) and fear of failure (FFR) - are statistically significant, but their signs are contrary to the theory. For example, $1 \%$ increase in the cost of enforcing contracts is associated with a $0.34 \%$ increase in TEA and this effect is statistically significant at $1 \%$. One possible explanation for this result is that many governments allocated financial resources towards programs that support 
new firms creation during the latest global financial crisis and thus overcome administrative barriers and fear of failure.

In an augmented model (Column 4), we include an interaction variable between SMAF and PECA to assess whether there is an additional impact of access to finance when the individuals has the required level of knowledge and skills to start a new venture. Our results suggest that a business environment characterized by a favorable access to finance offers to the individuals the opportunity for "grasping the fruits of knowledge". In other words, access to finance seems to play a more important role for the individuals who consider having the required skills and knowledge to start a new business.

Political stability and economic freedom seem to lead to more favorable conditions for starting new businesses, but these results are statistically significant only for OLS pooled regressions. In addition, contrary to our expectations, the level of corruption is positively related to entrepreneurial activity in OLS pooled regressions.

To test the robustness of our results, we use another measure for access to finance, namely informal investors rate. The results for the second model employing risk capital as a proxy for access to finance (Columns 5-7) are broadly in line with those obtained for the first model. The impact of informal funding (IIR) on TEA is more pronounced than for the first dependent variable.

Our results show that access to finance explains the differences in entrepreneurial activity across EU countries over the period between 2007 and 2013 in all models. These results agree with previous findings on different samples of countries and period, showing that access to finance positively influences entrepreneurial activity $[11,22]$. We contribute to the extant literature by introducing two new proxies for access to finance, one of them controlling for various sources of financing (debt and equity). Furthermore, we show that access to finance plays a more important role for the individuals who consider having the required skills and knowledge to start a business.

The results of the fixed effects panel models suggest a positive relationship between the economic growth and total entrepreneurial activity. Similar to other studies [40], our results suggest a strong positive relationship between individual characteristics (perceived capabilities) and total entrepreneurial activity. We found a negative relationship between fear of failure and enforcing contracts, on the one hand, and entrepreneurial activity, on the other hand. Contrary to our expectations, institutional factors such as the level of corruption, economic freedom, and political stability do not affect entrepreneurial activity. Overall, the results enlarge our knowledge of the existing differences in entrepreneurial activity among countries.

\subsection{Robustness Checks}

We tested the robustness of our findings by employing as dependent variables the components of TEA (NER and NBOR). Tables 5 and 6 present the results for these two dependent variables using the same proxies for access to finance (the model specification is given in the headline of the tables). Employing the nascent entrepreneurship rate and new business ownership rate as dependent variables, we obtain similar results to those in Table 4 . The sign and the significance of access to finance variables remain the same in the NER models, but the value of the coefficients is lower than in the TEA models. When we employ NBOR as dependent variables, most of the coefficients are statistically significant and the significant coefficients have the same sign as in the previous estimations.

As the correlation between GCI and CORRUP was very high, we also ran our models by replacing CORRUP with GCI. The results of the fixed effects models (not reported here, but available upon request) are broadly in line with the previous ones.

We also tested the existence of a non-monotonic relationship between access to finance and entrepreneurial activity for our sample by including the quadratic terms of access to finance, but the coefficients of the quadratic term were not statistically significant in our estimations. 
Table 5. Empirical results: NER models.

\begin{tabular}{|c|c|c|c|c|c|c|}
\hline \multirow{2}{*}{$\begin{array}{l}\text { Variables } \\
\text { (1) }\end{array}$} & \multicolumn{3}{|c|}{ Model 1} & \multicolumn{3}{|c|}{ Model 2} \\
\hline & $\begin{array}{l}\text { Pooled OLS } \\
\text { (2) }\end{array}$ & $\begin{array}{l}\mathrm{FE} \\
(3)\end{array}$ & $\begin{array}{l}\mathrm{FE} \\
(\mathbf{4})\end{array}$ & $\begin{array}{l}\text { Pooled OLS } \\
\text { (5) }\end{array}$ & $\begin{array}{l}\mathrm{FE} \\
(6)\end{array}$ & $\begin{array}{l}\mathrm{FE} \\
(7)\end{array}$ \\
\hline C & $\begin{array}{l}-12.58127 \\
(3.337492)\end{array}$ & $\begin{array}{l}-4.116542 \\
(5.324497)\end{array}$ & $\begin{array}{l}-18.31725 \\
(9.812468)\end{array}$ & $\begin{array}{l}-6.127429 \\
(2.302773)\end{array}$ & $\begin{array}{c}3.261115 \\
(5.256797)\end{array}$ & $\begin{array}{c}1.967034 \\
(5.366766)\end{array}$ \\
\hline SMAF & $\begin{array}{l}0.038344^{* * *} \\
(0.014164)\end{array}$ & $\begin{array}{c}0.054514^{* * *} \\
(0.015651)\end{array}$ & $\begin{array}{l}0.190599^{* *} \\
(0.080800)\end{array}$ & - & - & - \\
\hline IIR & - & - & - & $\begin{array}{c}0.455468^{* * *} \\
(0.062100)\end{array}$ & $\begin{array}{c}0.415178^{* * *} \\
(0.096065)\end{array}$ & $\begin{array}{l}0.975234 * \\
(0.495702)\end{array}$ \\
\hline ENCO & $\begin{array}{c}-2.64 \times 10^{-5} \\
(0.019728)\end{array}$ & $\begin{array}{c}0.254723^{* * *} \\
(0.067666)\end{array}$ & $\begin{array}{c}0.216848^{* * *} \\
(0.070558)\end{array}$ & $\begin{array}{l}-0.001067 \\
(0.017132)\end{array}$ & $\begin{array}{c}0.210154^{* * *} \\
(0.067220)\end{array}$ & $\begin{array}{c}0.214177^{* * *} \\
(0.067196)\end{array}$ \\
\hline EXBU & $\begin{array}{c}0.202343 \\
(0.152141)\end{array}$ & $\begin{array}{l}-0.403123 \\
(0.542049)\end{array}$ & $\begin{array}{l}-0.252734 \\
(0.543958)\end{array}$ & $\begin{array}{c}0.221857 \\
(0.134060)\end{array}$ & $\begin{array}{c}-1.081193 \text { ** } \\
(0.538570)\end{array}$ & $\begin{array}{c}-1.192669^{* *} \\
(0.546293)\end{array}$ \\
\hline FFR & $\begin{array}{l}0.043740 \text { ** } \\
(0.021700)\end{array}$ & $\begin{array}{l}0.038191 * \\
(0.021487)\end{array}$ & $\begin{array}{c}0.034070 \\
(0.021416)\end{array}$ & $\begin{array}{l}0.040939 * * \\
(0.018957)\end{array}$ & $\begin{array}{c}0.023278 \\
(0.021369)\end{array}$ & $\begin{array}{c}0.026349 \\
(0.021499)\end{array}$ \\
\hline PECA & $\begin{array}{c}0.065131^{* * *} \\
(0.017857)\end{array}$ & $\begin{array}{l}0.025215^{*} \\
(0.027741) \\
\end{array}$ & $\begin{array}{l}0.330677^{*} \\
(0.180105) \\
\end{array}$ & $\begin{array}{c}0.058742^{* * *} \\
(0.015510) \\
\end{array}$ & $\begin{array}{l}0.004421^{* *} \\
(0.028427) \\
\end{array}$ & $\begin{array}{l}0.035560^{*} \\
(0.044841) \\
\end{array}$ \\
\hline GDPCG & $\begin{array}{c}0.083354 * * * \\
(0.029846)\end{array}$ & $\begin{array}{l}0.048620 * \\
(0.027064)\end{array}$ & $\begin{array}{l}0.054843^{* *} \\
(0.027049)\end{array}$ & $\begin{array}{c}0.083664^{* * *} \\
(0.025902)\end{array}$ & $\begin{array}{l}0.051983^{*} \\
(0.027008)\end{array}$ & $\begin{array}{c}0.044135 \\
(0.027810)\end{array}$ \\
\hline CORRUP & $\begin{array}{l}1.396933 * * * \\
(0.279911)\end{array}$ & $\begin{array}{l}-0.150340 \\
(-0.150340)\end{array}$ & $\begin{array}{l}-0.022963 \\
(1.074540)\end{array}$ & $\begin{array}{l}0.462393 * \\
(0.261169)\end{array}$ & $\begin{array}{c}0.027008 \\
(1.103794)\end{array}$ & $\begin{array}{l}-0.477506 \\
(1.113344)\end{array}$ \\
\hline POL & $\begin{array}{l}0.826202 * * \\
(0.415190)\end{array}$ & $\begin{array}{l}-0.313664 \\
(0.879525) \\
\end{array}$ & $\begin{array}{l}-0.131680 \\
(0.877525) \\
\end{array}$ & $\begin{array}{l}0.591748^{*} \\
(0.338782) \\
\end{array}$ & $\begin{array}{c}0.531330 \\
(0.840364) \\
\end{array}$ & $\begin{array}{c}0.703893 \\
(0.852204) \\
\end{array}$ \\
\hline IEF & $\begin{array}{c}0.118306^{* * *} \\
(0.033948)\end{array}$ & $\begin{array}{l}-0.054689 \\
(0.057510)\end{array}$ & $\begin{array}{l}-0.037825 \\
(0.057800)\end{array}$ & $\begin{array}{l}0.050032 * \\
(0.029655)\end{array}$ & $\begin{array}{l}-0.036892 \\
(0.059167)\end{array}$ & $\begin{array}{l}-0.038127 \\
(0.059075)\end{array}$ \\
\hline $\mathrm{SMAF} \times \mathrm{PECA}$ & & & $\begin{array}{l}0.003122 * \\
(0.001819)\end{array}$ & & & \\
\hline IIR $\times$ PECA & & & & & & $\begin{array}{l}0.012945^{*} \\
(0.011241) \\
\end{array}$ \\
\hline R-squared & 0.362364 & 0.727068 & 0.734952 & 0.535220 & 0.747797 & 0.751305 \\
\hline Adjusted R-squared & 0.316084 & 0.637000 & 0.643926 & 0.500069 & 0.660189 & 0.661352 \\
\hline $\begin{array}{c}\text { Total panel (unbalanced) } \\
\text { observations }\end{array}$ & 134 & 134 & 134 & 129 & 129 & 129 \\
\hline
\end{tabular}

Source: Research results. Notes: Standard error in parentheses; ${ }^{* * *} p<0.01,{ }^{* *} p<0.05,{ }^{*} p<0.1$.

Table 6. Empirical results: NBOR models.

\begin{tabular}{|c|c|c|c|c|c|c|}
\hline \multirow{2}{*}{$\begin{array}{l}\text { Variables } \\
\text { (1) }\end{array}$} & \multicolumn{3}{|c|}{ Model 1} & \multicolumn{3}{|c|}{ Model 2} \\
\hline & $\begin{array}{l}\text { Pooled OLS } \\
\text { (2) }\end{array}$ & $\begin{array}{l}\text { FE } \\
(3)\end{array}$ & $\begin{array}{l}\mathrm{FE} \\
(4)\end{array}$ & $\begin{array}{l}\text { Pooled OLS } \\
\text { (5) }\end{array}$ & $\begin{array}{l}\text { FE } \\
(6)\end{array}$ & $\begin{array}{l}\text { FE } \\
(7)\end{array}$ \\
\hline $\mathrm{C}$ & $\begin{array}{l}-9.864654 \\
(2.494999)\end{array}$ & $\begin{array}{l}-5.691319 \\
(4.036355)\end{array}$ & $\begin{array}{l}-15.47618 \\
(7.457772)\end{array}$ & $\begin{array}{l}-9.044196 \\
(1.860241)\end{array}$ & $\begin{array}{l}-2.259810 \\
(4.094648)\end{array}$ & $\begin{array}{l}-2.391615 \\
(4.209188)\end{array}$ \\
\hline SMAF & $\begin{array}{c}0.004506 \\
(0.010589)\end{array}$ & $\begin{array}{c}0.019638^{* *} \\
(0.011865)\end{array}$ & $\begin{array}{l}0.113407^{*} \\
(0.061410)\end{array}$ & - & - & - \\
\hline IIR & - & - & - & $\begin{array}{c}0.218059 * * * \\
(0.050166)\end{array}$ & $\begin{array}{c}0.128249 * * \\
(0.074828)\end{array}$ & $\begin{array}{l}0.185292 * \\
(0.388782)\end{array}$ \\
\hline ENCO & $\begin{array}{l}-0.000383 \\
(0.014748)\end{array}$ & $\begin{array}{l}0.098154 * \\
(0.051296)\end{array}$ & $\begin{array}{c}0.072056 \\
(0.053626)\end{array}$ & $\begin{array}{l}-0.006644 \\
(0.013840)\end{array}$ & $\begin{array}{c}0.084875 \\
(0.052359)\end{array}$ & $\begin{array}{c}0.085285 \\
(0.052702)\end{array}$ \\
\hline EXBU & $\begin{array}{c}0.078458 \\
(0.113736)\end{array}$ & $\begin{array}{l}-0.288501 \\
(0.410912)\end{array}$ & $\begin{array}{l}-0.184877 \\
(0.413425)\end{array}$ & $\begin{array}{c}0.096147 \\
(0.108297)\end{array}$ & $\begin{array}{l}-0.519482 \\
(0.419505)\end{array}$ & $\begin{array}{l}-0.530836 \\
(0.428461)\end{array}$ \\
\hline FFR & $\begin{array}{l}0.032719^{* *} \\
(0.016222)\end{array}$ & $\begin{array}{c}0.047696^{* * *} \\
(0.016288)\end{array}$ & $\begin{array}{c}0.044857^{* * *} \\
(0.016277)\end{array}$ & $\begin{array}{l}0.033973 \text { ** } \\
(0.015314)\end{array}$ & $\begin{array}{c}0.042762 * * \\
(0.016645)\end{array}$ & $\begin{array}{c}0.043075^{* *} \\
(0.016861)\end{array}$ \\
\hline PECA & $\begin{array}{c}0.064715^{* * *} \\
(0.013349)\end{array}$ & $\begin{array}{c}0.083802 * * * \\
(0.021030)\end{array}$ & $\begin{array}{l}0.294277^{* *} \\
(0.136885)\end{array}$ & $\begin{array}{c}0.064127^{* * *} \\
(0.012529)\end{array}$ & $\begin{array}{c}0.075566^{* * *} \\
(0.022143)\end{array}$ & $\begin{array}{c}0.079638^{* *} \\
(0.035169)\end{array}$ \\
\hline GDPCG & $\begin{array}{l}0.046307^{* *} \\
(0.022312)\end{array}$ & $\begin{array}{c}0.042841 \text { ** } \\
(0.020517)\end{array}$ & $\begin{array}{l}0.047128 * * \\
(0.020558)\end{array}$ & $\begin{array}{l}0.052674 * * \\
(0.020925)\end{array}$ & $\begin{array}{c}0.046566 * * \\
(0.021037)\end{array}$ & $\begin{array}{c}0.045767^{* *} \\
(0.021811)\end{array}$ \\
\hline
\end{tabular}


Table 6. Cont.

\begin{tabular}{|c|c|c|c|c|c|c|}
\hline \multirow{2}{*}{$\begin{array}{l}\text { Variables } \\
\text { (1) }\end{array}$} & \multicolumn{3}{|c|}{ Model 1} & \multicolumn{3}{|c|}{ Model 2} \\
\hline & $\begin{array}{l}\text { Pooled OLS } \\
\text { (2) }\end{array}$ & $\begin{array}{l}\mathrm{FE} \\
(3)\end{array}$ & $\begin{array}{l}\mathrm{FE} \\
(4)\end{array}$ & $\begin{array}{l}\text { Pooled OLS } \\
\text { (5) }\end{array}$ & $\begin{array}{l}\text { FE } \\
\text { (6) }\end{array}$ & $\begin{array}{l}\text { FE } \\
\text { (7) }\end{array}$ \\
\hline CORRUP & $\begin{array}{l}0.641461^{* * *} \\
(0.209252)\end{array}$ & $\begin{array}{c}0.545008 \\
(0.820499)\end{array}$ & $\begin{array}{c}0.632776 \\
(0.816683)\end{array}$ & $\begin{array}{c}0.283009 \\
(0.210979)\end{array}$ & $\begin{array}{c}0.589592 \\
(0.859772)\end{array}$ & $\begin{array}{c}0.608263 \\
(0.873203)\end{array}$ \\
\hline POL & $\begin{array}{c}0.226989 \\
(0.310382)\end{array}$ & $\begin{array}{l}-0.887404 \\
(0.666744)\end{array}$ & $\begin{array}{l}-0.762009 \\
(0.666946)\end{array}$ & $\begin{array}{l}-0.047506 \\
(0.273677)\end{array}$ & $\begin{array}{l}-0.641680 \\
(0.654580)\end{array}$ & $\begin{array}{l}-0.624104 \\
(0.668389)\end{array}$ \\
\hline IEF & $\begin{array}{l}0.122732 * * * \\
(0.025378)\end{array}$ & $\begin{array}{c}0.020566 \\
(0.043596)\end{array}$ & $\begin{array}{c}0.032186 \\
(0.043930)\end{array}$ & $\begin{array}{l}0.103680^{* * *} \\
(0.023956)\end{array}$ & $\begin{array}{c}0.017404 \\
(0.046086)\end{array}$ & $\begin{array}{c}0.017279 \\
(0.046333)\end{array}$ \\
\hline $\mathrm{SMAF} \times \mathrm{PECA}$ & & & $\begin{array}{l}0.002151 * \\
(0.001383)\end{array}$ & & & \\
\hline $\mathrm{IIR} \times \mathrm{PECA}$ & & & & & & $\begin{array}{l}0.001318 * \\
(0.008816)\end{array}$ \\
\hline R-squared & 0.146903 & 0.697823 & 0.705035 & 0.412957 & 0.703839 & 0.703909 \\
\hline Adjusted R-squared & 0.099508 & 0.598104 & 0.603733 & 0.368559 & 0.600962 & 0.596813 \\
\hline $\begin{array}{c}\text { Total panel (unbalanced) } \\
\text { observations }\end{array}$ & 134 & 134 & 134 & 129 & 129 & 129 \\
\hline
\end{tabular}

Source: Research results. Notes: Standard error in parentheses. ${ }^{* * *} p<0.01,{ }^{* *} p<0.05,{ }^{*} p<0.1$.

\section{Conclusions}

The availability of financial resources—equity and debt—for small and medium enterprises represents an important condition for their creation, development, and survival. In the light of the latest global financial crisis, the lack of access to finance has been often cited as one the most significant barriers to start a new venture in many EU countries. Using a panel dataset containing information across countries and time, we investigate the role of access to finance in explaining cross-national differences in entrepreneurial activity across twenty-five EU members over the period between 2007 and 2013. The paper contributes to the financial literature through the expansion of the research concerning the determinants of entrepreneurial activity in EU member states in the light of the latest global financial crisis. Contrary to previous studies, we employ two different proxies for access to finance, one of them controlling for access to equity and debt in the EU member states. In addition, our paper extends the literature by analyzing the existence of an additional impact of access to finance and human capital (skills and knowledge) on entrepreneurial activity.

In this particular sample, we find a strong positive relationship between access to finance and total entrepreneurial activity (TEA). Our results proved to be robust for TEA underlying components (nascent entrepreneurship rate and new business ownership rate) and for different proxies for access to finance. Furthermore, we show that the impact of informal sources of financing (IIR) on entrepreneurial activity is higher than the traditional sources (debt and equity) included in SMAF index.

We also find a positive relationship between perceived capabilities and entrepreneurial activity. In an augmented model, we include the interaction effects between access to finance and human capital and the results suggest that the role of access to finance is more important for individuals who believe to have the required skills and knowledge to set up a new business. Macroeconomic environment positively influences entrepreneurial activity and this relationship is statistically significant in all estimations. Contrary to our expectations, the regulatory framework and fear of failure influence positively entrepreneurial activity, but these results can be explained by public programs to support entrepreneurship implemented in many EU countries during the latest global financial crisis. The results of the fixed effect panel models suggest that the level of corruption, economic freedom, and political stability do not influence entrepreneurial activity.

Our study is not without limitations. First, the inferences derived from this study are limited by the data on which the results are based. Second, we are aware that we employed a limited number of variables determining entrepreneurial activities. To assure the comparability of the two proxies for access to finance, we were forced to deal with the tradeoff between determinant variables, period of 
analysis, and sample of countries. Future research should include other quantitative and qualitative variables (such as bankruptcy laws) as soon as data will be available for new member states.

Author Contributions: All authors were involved in the documentation phase, in choosing the research methodology, in data analysis, as well as in result analysis and in discussions. All authors participated in the manuscript preparation and have approved the submitted manuscript.

Conflicts of Interest: The authors declare no conflict of interest.

\section{Appendix A}

Table A1. The evolution of SMAF index over the period 2007-2013 (EU = 100, 2007).

\begin{tabular}{cccccccc}
\hline Country & $\mathbf{2 0 0 7}$ & $\mathbf{2 0 0 8}$ & $\mathbf{2 0 0 9}$ & $\mathbf{2 0 1 0}$ & $\mathbf{2 0 1 1}$ & $\mathbf{2 0 1 2}$ & $\mathbf{2 0 1 3}$ \\
\hline Austria & 111.5 & 110.0 & 116.8 & 121.4 & 122.8 & 122.4 & 122.9 \\
Belgium & 105.9 & 103.4 & 106.4 & 105.5 & 106.3 & 108.7 & 111.5 \\
Bulgaria & 91.2 & 90.2 & 90.6 & 91.2 & 90.8 & 95.3 & 98.2 \\
Croatia & 97.6 & 96.5 & 99.5 & 106.9 & 112.2 & 114.7 & 111.9 \\
Cyprus & 106.0 & 105.8 & 105.5 & 105.9 & 94.9 & 95.3 & 82.3 \\
Czech Republic & 99.1 & 98.4 & 101.6 & 105.3 & 107.1 & 108.2 & 109.1 \\
Denmark & 105.1 & 103.4 & 104.5 & 105.9 & 106.4 & 106.6 & 110.5 \\
Estonia & 94.3 & 94.5 & 97.3 & 94.6 & 99.1 & 102.9 & 112.1 \\
Finland & 107.5 & 108.6 & 114.8 & 124.4 & 122.3 & 120.0 & 121.8 \\
France & 110.5 & 110.1 & 117.1 & 124.0 & 120.7 & 121.5 & 126.5 \\
Germany & 109.6 & 110.4 & 113.5 & 114.9 & 114.8 & 122.6 & 119.2 \\
Greece & 93.2 & 93.9 & 98.3 & 93.6 & 81.8 & 79.3 & 77.8 \\
Hungary & 80.8 & 78.2 & 74.6 & 86.4 & 91.4 & 95.5 & 94.6 \\
Ireland & 95.6 & 95.5 & 103.1 & 104.3 & 106.0 & 106.7 & 111.3 \\
Italy & 102.5 & 101.4 & 107.5 & 111.0 & 105.8 & 96.4 & 107.0 \\
Latvia & 83.2 & 84.0 & 77.3 & 97.2 & 110.3 & 110.7 & 109.1 \\
Lithuania & 92.1 & 90.4 & 92.4 & 100.2 & 103.9 & 110.3 & 116.4 \\
Luxembourg & 106.4 & 107.5 & 111.1 & 105.7 & 105.1 & 107.4 & 121.2 \\
Malta & 105.2 & 103.2 & 106.0 & 108.1 & 109.5 & 109.7 & 106.2 \\
Netherlands & 103.2 & 101.6 & 108.6 & 112.7 & 114.1 & 116.5 & 116.8 \\
Poland & 99.5 & 96.6 & 98.6 & 101.4 & 103.2 & 102.6 & 108.3 \\
Portugal & 95.3 & 95.1 & 97.4 & 99.2 & 92.2 & 86.7 & 97.3 \\
Romania & 89.7 & 87.0 & 84.5 & 92.0 & 92.9 & 95.5 & 84.9 \\
Slovak Republic & 106.6 & 106.7 & 111.7 & 110.1 & 105.5 & 106.7 & 111.7 \\
Slovenia & 103.1 & 101.5 & 104.4 & 107.9 & 109.9 & 112.2 & 114.2 \\
Spain & 85.9 & 83.8 & 80.8 & 89.9 & 100.3 & 95.6 & 101.2 \\
Sweden & 116.7 & 117.9 & 119.8 & 119.5 & 112.0 & 112.9 & 113.7 \\
United Kingdom & 102.2 & 104.7 & 112.4 & 110.9 & 107.3 & 106.5 & 111.5 \\
\hline
\end{tabular}

Source: European Commission [41]. 
Table A2. Correlation matrix

\begin{tabular}{|c|c|c|c|c|c|c|c|c|c|c|c|c|c|c|}
\hline & TEA & NER & NBOR & SMAF & IIR & ENCO & EXBU & FFR & PECA & GDPCG & GCI & CORRUP & POL & IEF \\
\hline TEA & 1.00 & 0.93 & 0.86 & -0.05 & 0.59 & 0.12 & 0.23 & 0.03 & 0.30 & 0.15 & -0.29 & 0.27 & 0.01 & 0.02 \\
\hline NER & 0.93 & 1.00 & 0.60 & -0.01 & 0.61 & 0.07 & 0.27 & 0.05 & 0.24 & 0.21 & -0.34 & 0.34 & 0.02 & -0.10 \\
\hline NBOR & 0.86 & 0.60 & 1.00 & -0.10 & 0.41 & 0.17 & 0.11 & 0.00 & 0.30 & 0.03 & -0.15 & 0.11 & -0.02 & 0.18 \\
\hline SMAF & -0.05 & -0.01 & -0.10 & 1.00 & 0.15 & 0.12 & -0.38 & -0.28 & -0.15 & 0.17 & 0.59 & -0.53 & 0.58 & 0.30 \\
\hline IIR & 0.59 & 0.61 & 0.41 & 0.15 & 1.00 & 0.16 & 0.06 & 0.00 & 0.05 & 0.24 & -0.20 & 0.23 & 0.07 & 0.00 \\
\hline ENCO & 0.12 & 0.07 & 0.17 & 0.12 & 0.16 & 1.00 & -0.28 & -0.05 & -0.08 & 0.09 & 0.23 & -0.10 & -0.03 & 0.42 \\
\hline EXBU & 0.23 & 0.27 & 0.11 & -0.38 & 0.06 & -0.28 & 1.00 & -0.15 & 0.27 & 0.06 & -0.51 & 0.48 & -0.10 & -0.36 \\
\hline FFR & 0.03 & 0.05 & 0.00 & -0.28 & 0.00 & -0.05 & -0.15 & 1.00 & -0.22 & -0.11 & -0.31 & 0.38 & -0.47 & -0.34 \\
\hline PECA & 0.30 & 0.24 & 0.30 & -0.15 & 0.05 & -0.08 & 0.27 & -0.22 & 1.00 & -0.11 & -0.36 & 0.24 & -0.13 & -0.23 \\
\hline GDPCG & 0.15 & 0.21 & 0.03 & 0.17 & 0.24 & 0.09 & 0.06 & -0.11 & -0.11 & 1.00 & 0.03 & 0.01 & 0.16 & 0.04 \\
\hline GCI & -0.29 & -0.34 & -0.15 & 0.59 & -0.20 & 0.23 & -0.51 & -0.31 & -0.36 & 0.03 & 1.00 & -0.95 & 0.53 & 0.62 \\
\hline CORRUP & 0.27 & 0.34 & 0.11 & -0.53 & 0.23 & -0.10 & 0.48 & 0.38 & 0.24 & 0.01 & -0.95 & 1.00 & -0.57 & -0.65 \\
\hline POL & 0.01 & 0.02 & -0.02 & 0.58 & 0.07 & -0.03 & -0.10 & -0.47 & -0.13 & 0.16 & 0.53 & -0.57 & 1.00 & 0.42 \\
\hline IEF & 0.02 & -0.10 & 0.18 & 0.30 & 0.00 & 0.42 & -0.36 & -0.34 & -0.23 & 0.04 & 0.62 & -0.65 & 0.42 & 1.00 \\
\hline
\end{tabular}




\section{References}

1. Acs, Z.J.; Audretsch, D.B. Innovation and Small Firms; MIT Press: Cambridge, UK, 2000.

2. Goel, R.K.; Göktepe-Hultén, D. Nascent entrepreneurship and inventive activity: A somewhat new perspective. J. Technol. Transf. 2013, 38, 471-485. [CrossRef]

3. Nițu-Antonie, R.D.; Feder, E.-S.; Munteanu, V.P. Macroeconomic Effects of Entrepreneurship from an International Perspective. Sustainability 2017, 9, 1159. [CrossRef]

4. Koellinger, P.; Thurik, R. Entrepreneurship and the business cycle. Rev. Econ. Stat. 2012, 94, 1143-1156. [CrossRef]

5. Taddeo, R.; Simboli, A.; Ioppolo, G.; Morgante, A. Industrial symbiosis, networking and innovation: The potential role of innovation poles. Sustainability 2017, 9, 169. [CrossRef]

6. Szopik-Depczyńska, K.; Cheba, K.; Bąk, I.; Kiba-Janiak, M.; Saniuk, S.; Dembińska, I.; Ioppolo, G. The application of relative taxonomy to the study of disproportions in the area of sustainable development of the European Union. Land Use Policy 2017, 68, 481-491. [CrossRef]

7. Arbolino, R.; Carlucci, F.; Cirà, A.; Ioppolo, G.; Yigitcanlar, T. Efficiency of the EU regulation on greenhouse gas emissions in Italy: The hierarchical cluster analysis approach. Ecol. Indic. 2017, 81, 115-123. [CrossRef]

8. Kwon, S.-W.; Arenius, P. Nations of entrepreneurs: A social capital perspective. J. Bus. Venturing 2010, 25, 315-330. [CrossRef]

9. Hitt, M.A.; Ireland, R.D.; Sirmon, D.G.; Trahms, C. Strategic entrepreneurship: Creating value for individuals, organizations and society. Acad. Manag. Perspect. 2011, 25, 57-75. [CrossRef]

10. De Clercq, D.; Meuleman, M.; Wright, M. A cross-country investigation of micro-angel investment activity: The roles of new business opportunities and institutions. Int. Bus. Rev. 2012, 21, 117-129. [CrossRef]

11. Morales Urrutia, D.; Rodil Marzábal, O. Factores explicativos de la creación de empresas en diez países europeos: Una propuesta desde la perspectiva institucional. Rev. Econ. Mund. 2015, 40, 91-122.

12. Wennekers, S.; Uhlaner, L.; Thurik, R. Entrepreneurship and Its Conditions: A Macro Perspective. Int. J. Entrep. Educ. 2002, 1, 25-68.

13. Robson, M. Explaining Cross-Country Variations in Entrepreneurship: The Role of Social Protection and Political Culture. Comp. Labor Law Policy J. 2007, 28, 863-892.

14. Freytag, A.; Thurik, R. Entrepreneurship and its determinants in a cross-country setting. J. Evol. Econ. 2007, 17, 117-131. [CrossRef]

15. Estrin, S.; Mickiewicz, T. Entrepreneurship in Transition Economies: The Role of Institutions and Generational Change, The Institute for the Study of Labor (IZA), Discussion Paper No. 4805. 2010. Available online: http:/ /ftp.iza.org/dp4805.pdf (accessed on 12 November 2016).

16. Ardagna, S.; Lusardi, A. Heterogeneity in the Effect of Regulation on Entrepreneurship and Entry Size. J. Eur. Econ. Assoc. 2010, 8, 594-605. [CrossRef]

17. Klapper, L.; Love, I. The Impact of the Financial Crisis on New Firm Registrations, The World Bank, Policy Research Working Paper 5444. 2010. Available online: https:/ / papers.ssrn.com/sol3/papers.cfm?abstract_ id=1691286\# (accessed on 10 March 2017).

18. Shinnar, R.S.; Giacomin, O.; Janssen, F. Entrepreneurial perceptions and intentions: The role of gender and culture. Entrep. Theory Pract. 2012, 36, 465-493. [CrossRef]

19. Goel, R.K.; Nelson, M.A.; Payne, J.E. Entrepreneurship and cross-national economic freedom. In Economic Behavior, Economic Freedom, and Entrepreneurship; Cebula, R.J., Hall, C., Mixon, F.G., Jr., Payne, J.E., Eds.; Edward Elgar Publishing: Cheltenham, UK, 2015; pp. 222-235.

20. Kerr, W.; Nanda, R. Financing Constraints and Entrepreneurship, National Bureau of Economic Research WP 15498. 2009. Available online: http:/ / www.nber.org/papers/w15498.pdf (accessed on 31 August 2017).

21. Klapper, L.; Amit, R.; Guillén, M.F. Entrepreneurship and firm formation across countries. In International Differences in Entrepreneurship; Lerner, J., Schoar, A., Eds.; University of Chicago Press: Chicago, IL, USA, 2010; pp. 129-158.

22. Nielsen, G. Determinants of cross-national entrepreneurial activity. J. Politics Soc. 2014, 25, 46-72.

23. Fraser, S.; Bhaumik, S.K.; Wright, M. What do we know about entrepreneurial finance and its relationship with growth? Int. Small Bus. J. 2015, 33, 70-88. [CrossRef]

24. Blanchflower, D.G.; Oswald, A.J. What Makes an Entrepreneur? J. Labor Econ. 1998, 16, 26-60. [CrossRef] 
25. Grilo, I.; Irigoyen, J.M. Entrepreneurship in the EU: To wish and not to be. Small Bus. Econ. 2006, 26, 305-318. [CrossRef]

26. De Clercq, D.; Lim, D.S.K.; Oh, C.H. Individual-Level Resources and New Business Activity: The Contingent Role of Institutional Context. Entrep. Theory Pract. 2013, 37, 303-330. [CrossRef]

27. European Central Bank. Survey on the Access to Finance of Enterprises (SAFE). Available online: https: / / www.ecb.europa.eu/stats/money/surveys/sme/html/index.en.html (accessed on 25 May 2016).

28. Global Entrepreneurship Monitor. Key Indicators and Definitions. 2011. Available online: http://www. gemconsortium.org/docs/download/414 (accessed on 1 July 2016).

29. Shane, S. Explaining variation in rates of entrepreneurship in the United States: 1899-1988. J. Manag. 1996, 22, 747-781. [CrossRef]

30. Van Gelderen, M.; Thurik, R.; Bosma, N. Success and risk factors in the pre-startup phase. Small Bus. Econ. 2006, 26, 319-335. [CrossRef]

31. Ho, Y.P.; Wong, P.K. Financing, regulatory costs and entrepreneurial propensity. Small Bus. Econ. 2007, 28, 187-204. [CrossRef]

32. Eurostat. Entrepreneurship Determinants: Culture and Capabilities. 2012. Available online: http://ec. europa.eu/eurostat/documents/3217494/5748437/KS-31-12-758-EN.PDF (accessed on 12 April 2016).

33. Sobel, R.; Clark, J.R.; Lee, D. Freedom, Barriers to Entry, Entrepreneurship, and Economic Progress. Rev. Austrian Econ. 2007, 20, 221-236. [CrossRef]

34. Costa, L.D.A.; Mainardes, E.W. The role of corruption and risk aversion in entrepreneurial intentions. Appl. Econ. Lett. 2016, 23, 290-293. [CrossRef]

35. Van Stel, A.; Wennekers, A.R.M.; Thurik, A.R.; Reynolds, P. Explaining Nascent Entrepreneurship across Countries, EIM Business and Policy Research, SCALES-Paper N2003-01. 2003. Available online: http: / / ondernemerschap.panteia.nl/pdf-ez/n200301.pdf (accessed on 16 April 2016).

36. Verheul, I.; Wennekers, A.R.M.; Audretsch, D.B.; Thurik, A.R. An eclectic theory of entrepreneurship. In Entrepreneurship: Determinants and Policy in a European-US Comparison; Audretsch, D.B., Thurik, A.R., Verheul, I., Wennekers, A.R.M., Eds.; Kluwer Academic Publishers: Boston, MA, USA; Dordrecht, The Netherlands, 2002; pp. 1-10.

37. Linan, F.; Fernandez, J.; Romero, I. Necessity and opportunity entrepreneurship: The mediating effect of culture. Rev. Econ. Mund. 2013, 33, 27-51.

38. World Economic Forum. Leveraging Entrepreneurial Ambition and Innovation: A Global Perspective on Entrepreneurship, Competitiveness and Development. 2015. Available online: http://www3.weforum.org/ docs/WEFUSA_EntrepreneurialInnovation_Report.pdf (accessed on 15 December 2016).

39. Dreher, A.; Gassebner, M. Greasing the wheels? The impact of regulations and corruption on firm entry. Public Choice 2013, 155, 413-432. [CrossRef]

40. Bosma, N.; Schutjens, V. Understanding regional variation in entrepreneurial activity and entrepreneurial attitude in Europe. Ann. Reg. Sci. 2011, 47, 711-742. [CrossRef]

41. European Commission. SMAF Index. Available online: http://lexicon-software.co.uk/enterprise/ policies / finance/data/enterprise-finance-index/sme-access-to-finance-index/index_en.htm (accessed on 15 July 2016).

(C) 2017 by the authors. Licensee MDPI, Basel, Switzerland. This article is an open access article distributed under the terms and conditions of the Creative Commons Attribution (CC BY) license (http:/ / creativecommons.org/licenses/by/4.0/). 